63 卷 $6018 \frac{1}{2} \frac{1}{5}(1997-4)$

\title{
スティフな断片線形系の時刻歴応答解析に関する研究* (付加質量法の提案)
}

\author{
今西 悦二郎*1, 廣 岡 栄 子*2, 井上 喜 雄*1
Time Historical Analysis Method for Stiff Piecewise-Linear System (Method of Adding Mass)

\author{
Etsujiro IMANISHI, Eiko HIROOKA and Yoshio INOUE
}

\begin{abstract}
We present a characteristic improvement method for time historical analysis of stiff piecewiselinear system by adding mass. Hydraulic power lines with check valves and control valves for construction machinery exhibit piecewise-linear characteristics for hydraulic flow rate and spool stroke. The proposed method involves no time delay in determining the mass by considering both eigenvalue distortion of the system and time response. This method is useful for time historical analysis of hydraulic power lines including stiff piecewise-linear elements such as check valves, relief valves and control valves.
\end{abstract}

Key Words: Nonlinear Vibration, Oil Hydraulics, Numerical Integration, Dynamic Simulation

\section{1. 緒言}

最近の建設機械では，操作性や乗り心地の向上に関 する要求が高まっている。そのため, 新機種の開発設 計段階に抢ける事前評価技術の確立が求められてい る. 建設機械では動力として油圧が用いられており， その動特性を把握することが評価技術を確立させる上 で重要な課題となる.

著者らは, 以前から油圧パワーラインを含む建設機 械の動的シミュレーション(1)(2)を実施してきた. しか し, 油压機器のなかでもチェック弁などのように流量 に対して強い非線形性を示す機器や，スライドスプー ル形方何制御弁 (以ト，コントロール弁と呼ぶ)などの ようにスプール変位に対して強い非線形性を示す機器 を取扱う場命には，Newmark- $\beta$ 法を用いた数值積分 の特性が大きく変化してしまう。このような場合に精 度を確保するためには、時間刻みを小さくするなどの 注意を要した。そのため, 自由度が大きくなると計算 時間が膨大になり，設計者向けの解析ツールとして活

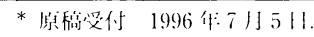

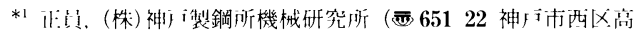
㧴吉i $15-5)$.

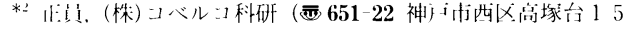
,)
用するには, 数值積分の特性を改善する必要性が生じ た.

そこで本報では, チェック弁やコントロール弁のよ うなスティフな断片線形要素を含む系の時刻歴応答解 析法において, 数值積分の特性を改善する方法として 時間刻みに対応した質量を付加する手法(以下，付加 質量法と呼称する)を提案する．付加質量の大きさは， 清水ら (3) が提案した数值積分に関連する固有值のひ ずみに着目した手法を用いることによって, 数值積分 の特性を改善し，かつ応答性に影響を与えないように 決めることができる，本手法は，時間刻みが大きくて も断片線形要素の折れ曲がり点の通過を容易にし, 応 答性能に影響を与えず，かつ夕フに解析することを可 能にする。

\section{2. 断片線形系における解析理論}

$2 \cdot 1$ 運動方程式油圧系を含む機械システムの 動的シミュレーションを実施するに際して, 通常の有 限要素法の場合と同様に, 系全体をあらかじめ準備さ れた標準要素を用いてモデル化し, 次式のような運動 方程式を生成する.

$$
[M] \ddot{\boldsymbol{x}}+[C] \dot{\boldsymbol{x}}+[K] \boldsymbol{x}=\boldsymbol{f}
$$

ここで, $x$ は機械系では変位, 油压系では流量の積分 


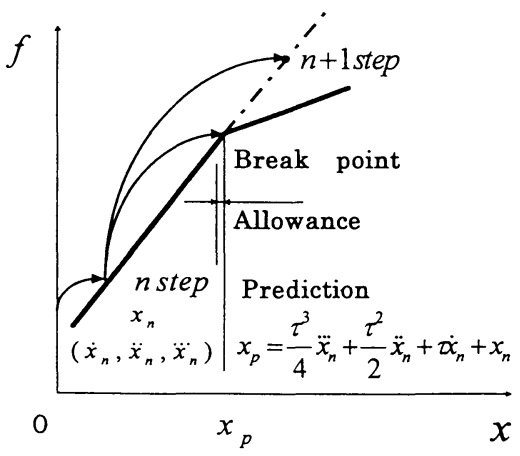

Fig. 1 Break point passing algorithm

值を表す状態べクトルであり, $\boldsymbol{f}$ は外力, 圧力を表す 外力ベクトルである. $[M],[C],[K]$ はそれぞれ質量, 減衰, 剛性マトリックスであり, 線形問題では $[M]$, $[C],[K]$ は一定であるが, 非線形問題では $\boldsymbol{x}, \dot{\boldsymbol{x}}$ など の関数となるので, 各時間ステップごとに断片線形化 し各マトリックスに組込む。

$2 \cdot 2$ 折れ曲がり点通過アルゴリズム 断片線形 系における折れ曲がり点通過アルゴリズムは, 通過直 前の状態量を用いて折れ曲がり点を予測する手法(4) を採用している。ここでは，変位に対する断片線形要 素について説明する. 図 1 に示すように $n+1$ ステッ プにおいてある断片線形要素が折れ曲がり点を通過し た場合, $n$ ステップの状態に戻り，そのときの状態量 (変位 $x_{n}$, 速度 $\dot{x}_{n}$, 加速度 $\ddot{x}_{n}$, 加加速度 $\dddot{x}_{n}$ ) 加ら次 式を用いて折れ曲がり点 $x_{p}$ を予測し,

$$
x_{p}=x_{n}+\tau \dot{x}_{n}+\tau^{2} \ddot{x}_{n} / 2+\tau^{3} \dddot{x}_{n} / 4
$$

折れ曲がり点の手前に設けた許容範囲に入るように時 間刻みを調節する.そのため, 状態量が数值的にひず まされていると正確な予測が難しくなり, 逆に計算時 間がかかってしまう恐れがある。そこで，以下ではス ティフな断片線形要素として, 減衰特性が大きく変化 する高減衰断片線形要素，および剛性特性が大きく変 化する高剛性断片線形要素を取り上げ，それぞれの要 素を含む系に対するNewmark- $\beta$ 法 $(\beta=1 / 4)$ を用い た時刻歴応答解析法において, 数值積分の特性を改善 する付加質量法の検討を行う.

\section{3. 高減衰断片線形系の挙動と精度検討}

$3 \cdot 1$ 高減衰断片線形系の挙動まず, 高減衰断 片線形要素を含む油圧系におけるモデル化と, その挙 動について示す。そこで, 図 2(a)に示すような油圧 系に高減衰断片線形要素としてチェック弁が取付けら れているモデルを考える。油圧系は, 作動油の質量お

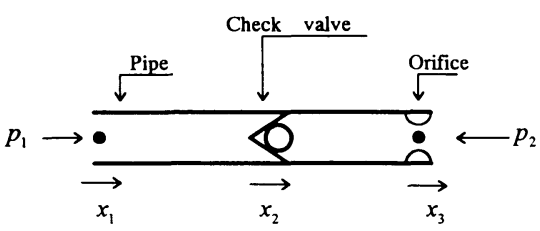

(a) Hydraulic power line

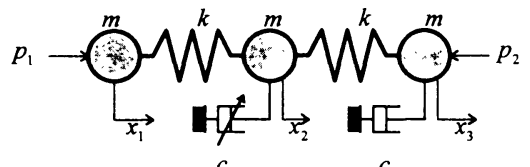

$c_{2} \quad c_{3}$

$m=0.01 \mathrm{~kg} / \mathrm{m}^{4}, c_{3}=0.5 \mathrm{Pas} / \mathrm{m}^{3}$

$k=100 . P a / m^{3}, \tau=0.001 s$

(b) Check valve model

Fig. 2 Hydraulic power line model

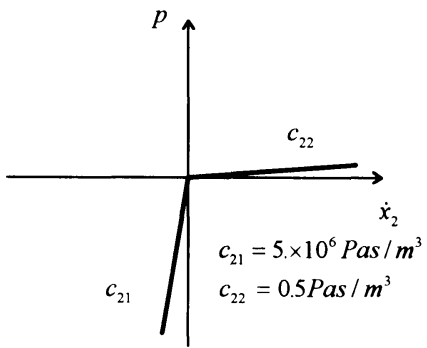

Fig. 3 Nonlinear characteristics of check valve

よび圧縮性を考慮すると, 図 2 (b) に示すように 3 自 由度のばね質点系にモデル化することができる(2). な お, チェック弁はポペット部の応答性が, 他の油圧系 の動特性に比べて無視できる場合を考える．この時の チェック弁の流量特性は, 正方向の流量に対してはあ る圧力損失が存在し，負の方向の流量に対しては流れ ないという特性である。これを断片線形系としてモデ ル化したものが, 図 3 である.この場合, 流れないと いうモデル化は, 減衰係数 $c_{21}$ を正方向の減衰係数 $c_{22}$ より十分大きな值 $\left(10^{7}\right.$ 倍)として，モデル化している. また，油圧系右端に取付けられたオリフィスは，流量 に比例した圧力損失を示すものとする.

この系に図 $4(\mathrm{a})$ に示すような圧力 $p_{1}, p_{2}$ が, それ ぞれ左端と右端に作用したときの応答を解析する。時 間刻みは，実固有值解析から決まる最高次の固有周期 $(0.037 \mathrm{~s})$ の $1 / 20$ 以下である $0.001 \mathrm{~s}$ とした。このと きの流量 $\dot{x}$ と加速度 $\ddot{x}$ を図 4(b), (c)に示す。こ れらの図から， $\ddot{x}$ が時間 $3 \sim 7 \mathrm{~s}$ において, 時間刻みご とに大きく振動していることがわかる。これは，時間 


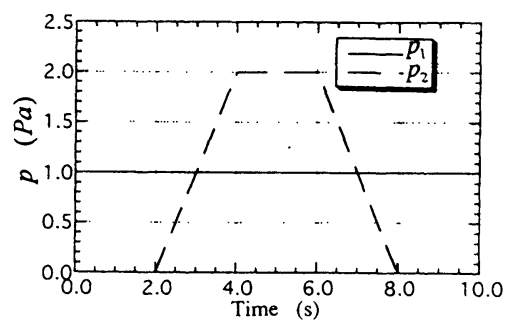

(a) Pressure change

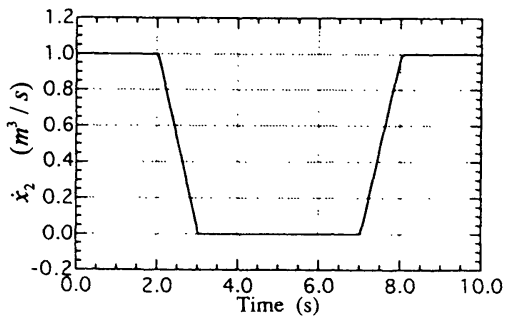

(b) Flow rate

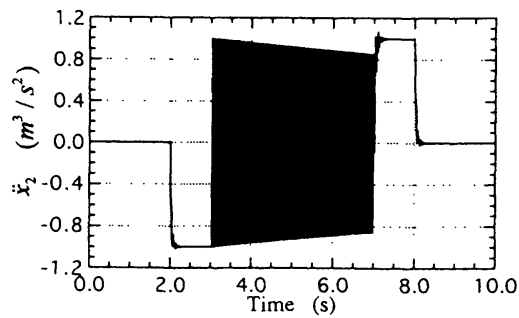

(c) Acceleration

Fig. 4 Simulation results of check valve model

0〜 $3 \mathrm{~s}$ ではチェック弁部の隇衰係数は $c_{22}$ であるが, 時間 3〜 $7 \mathrm{~s}$ では $c_{21}$ となるためと考えられる。 そのた め, $\ddot{x}$ を用いて折れ曲がり点を予測するためには，十 分小さな時間刻みにする必要があり, 解析時間も増加 する。そこで，時間刻みを大きくしても精度よく折れ 曲がり点を予測できる手法として, 減衰係数と時間刻 みに比例した質量を付加する手法(付加質量法)の検討 を行う。

$3 \cdot 2$ 数値積分法の性質 付加質量法による高減 衰断片線形系の数值積分における特性改善効果を評価 するために，清水ら (3) が提案した数值積分に関連する 固有值のひずみに着目した手法を用いて，その性質を 検討する。ここでは簡単化のため，1 自由度の減衰一質 点系モデルを考える。この系の運動方程式は, 外力項 を無視すると次式のようになる。

$m \ddot{x}+c \dot{x}=0$

ここで, $x=X e^{-\alpha_{0} t}$ とおき整理すると, 1 次系の固有 值 $\alpha_{0}$ が得られる.

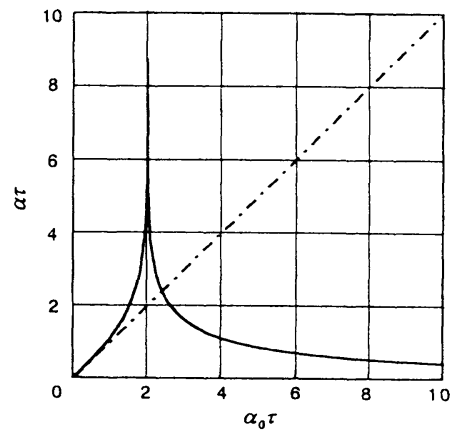

Fig. 5 Eigenvalue distortion $\alpha \tau$ vs. $\alpha_{0} \tau$

$\alpha_{0}=\mathrm{c} / \mathrm{m}$

一方, この系に対するNewmark- $\beta$ 法 $(\beta=1 / 4)$ の特 性方程式 $z=e^{-\alpha \tau}$ は, 差分方程式を $z$ 変換することに よって, 次式のように与えられる(3).

$$
\left(1+\frac{\alpha_{0} \tau}{2}\right) z^{2}-2 z+\left(1-\frac{\alpha_{0} \tau}{2}\right)=0 \cdots
$$

ここで, $\tau$ は時間刻みである.上式を $z$ に関して解き, さらに対数変換すると次式が得られる.

$$
\alpha \tau=-\ln \left|\frac{1-\frac{\alpha_{0} \tau}{2}}{1+\frac{\alpha_{0} \tau}{2}}\right|
$$

上式は, 系の固有值と時間刻みの積 $\alpha_{0} \tau$ がNewmark$\beta$ 法によって $\alpha \tau$ にひずまされることを示す. $\alpha_{0} \tau$ と $\alpha \tau$ の関係を図 5 に示す. 図 2 に示す油圧系では, 節 点 2 における $\alpha_{0} \tau\left(=c_{2} \tau / m_{2}\right)$ はチェック弁の隇衰係数 $C_{22}, C_{21}$ によって $5 . \times 10^{-2}$ から $5 . \times 10^{5}$ まで変化してい ることがわかる， $\alpha_{0} \tau=5 . \times 10^{-2}$ では， $\alpha \tau / \alpha_{0} \tau \cong 1$ とな るが, $\alpha_{0} \tau=5 . \times 10^{5}$ では $\alpha \tau / \alpha_{0} \tau \cong 0$ となり, 固有值が 大きくひずまされていることがわかる.

$3 \cdot 3$ 付加質量法による特性の改善 $3 \cdot 2$ 節の検 討によって高減衰断片線形要素に対しては, 時間刻み を小さくすることなく, 付加質量 $\Delta m$ を与えることに よって $\alpha_{0} \tau$ を小さくし, 数值積分の特性を改善するこ とができそうである。しかし，あまり大きな $\Delta m$ を与 えると, 応答性が悪化し解析結果に悪影響を与える可 能性がある。そこで, 1 自由度の減衰-質点系モデルを 用いて， $\alpha_{0} \tau$ を変化させたときのステップ応答特性を 検討する。

まず, $c \tau$ を一定にし， $m$ を変化させることによっ て $\alpha_{0} \tau=c \tau / m$ を変化させたときの解析結果を, 図 6 に 示す.この図から， $m$ を大きくして $\alpha_{0} \tau$ を小さくする と, 流量 $\dot{x}$ が滑らかに変化しているが, $m$ を小さく して $\alpha_{0} \tau$ を大きくすると, $\dot{x}$ の変化が激しくなり, $\alpha_{0} \tau=10^{3}$ では時間刻みごとに振動していることがわ 


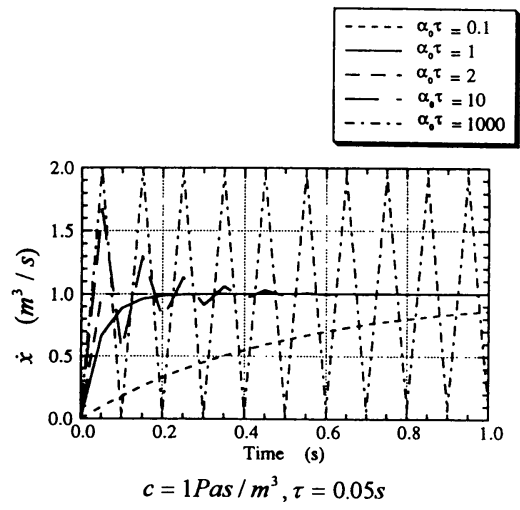

Fig. 6 Step response characteristics by adding mass

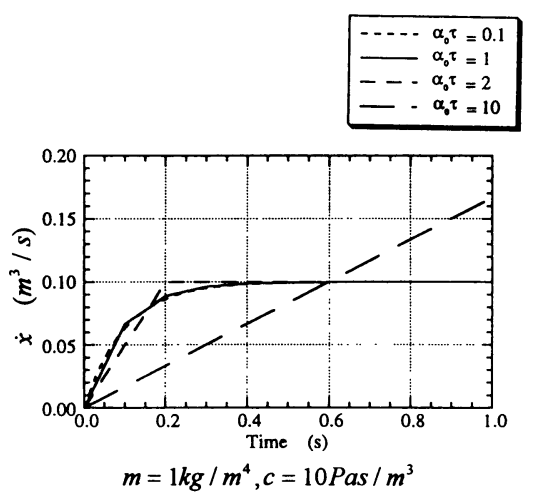

Fig. 7 Step response characteristics by changing time step

かる.

一方, $\alpha_{0}=c / m$ を一定にし， $\tau$ を変化させたときの 解析結果を図 7 に示す。この場合, 流量に対する時定 数 $T$ は $T=m / c=0.1 \mathrm{~s}$ となるが, 時間遅れは $\alpha_{0} \tau=1$ までは大きくないことがわかる。しかも，このときの 時定数は $T=1 / \alpha_{0}=\tau$ となっていることがわかる. 通 常, 時間刻み $\tau$ の選定に際しては, 解析したい挙動を 十分表現できる程度に小さくしており， $\alpha_{0} \tau=1$ となる ように $m$ を決めても応答性には影響を与えないこと がわかる.

以上の検討結果から, 高減衰断片線形要素に対して は, $\alpha_{0} \tau=1$ すなわち $\Delta m=c \tau$ となるように付加質量 を与えることによって，応答性に影響を与えず，しか も流量 $\dot{x}$ および加速度 $\ddot{x}$ の精度が向上することによ って，折れ曲がり点の予測を容易にすることができ る.

$3 \cdot 4$ 解析例 ここでは, 付加質量法の妥当性を

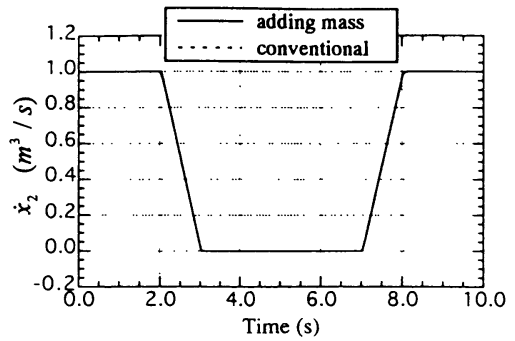

(a) Flow rate

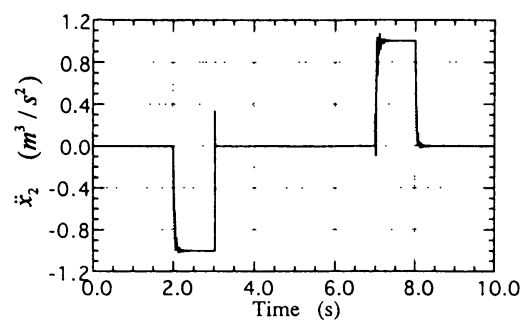

(b) Acceleration

Fig. 8 Simulation results by adding mass

検証するために, 図 2 に示した油圧系の解析を行う。 3 ・3 節において示したように, チェック弁の減衰係数 $c_{2}\left(c_{21}, c_{22}\right)$ に比例した付加質量 $\Delta m_{2}=c_{2} \tau$ を計算し, 各時間ステップごとにチェック弁部に組込み, 図 4 と 同様の解析を行った. その結果を図 8 に示す。この図 から, 時間 3〜 $7 \mathrm{~s}$ においても加速度 $\ddot{x}$ の変動は小さ く抑えられており，しかも流量の応答性に関しては付 加質量を与えていないときの結果と同等であることが わかる。 また, 折れ曲がり点通過に関する繰返し計算 回数は, 9363 回から 2 回に減少した.

\section{4. 高剛性断片線形系の挙動と精度検討}

$4 \cdot 1$ 高剛性断片線形系の挙動 次に, 高剛性断 片線形要素を含む油圧系におけるモデル化と, その挙 動について示す.そこで, 図 9 に示すように高剛性断 片線形要素としてコントロール弁モデルを考える、コ ントロール弁のスプール部にはばねが取付けられてお り,さらにストローク制限のためストッパが設けられ ている。このときのコントロール弁スプール部のばね 特性を断片線形系としてモデル化したものが, 図 10 である，この場合ストッパのモデル化は，ばね定数 $k_{1}$ を原点付近のスプール部ばね定数 $k_{2}$ より十分大きな 值 $\left(10^{6}\right.$ 倍)として, モデル化している。 また，スプー ル部には線形な減衰が作用しているものとし, 减衰比 を原点付近では 0.1 ，ストッパ部では 1 とした。

この系に図11(a)に示すようなパイロット力 $f$ が 

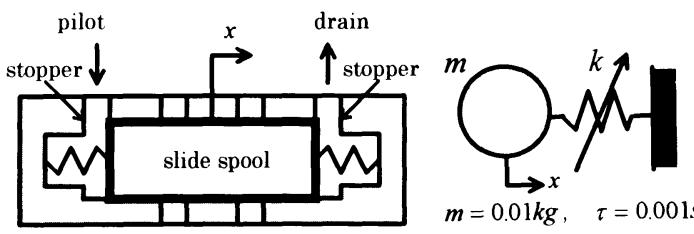

Fig. 9 Control valve model

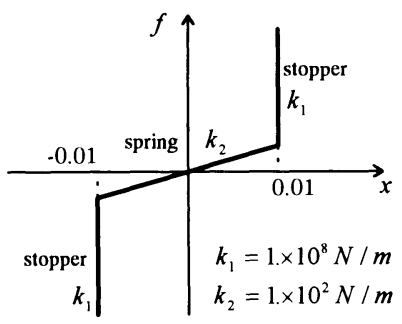

Fig. 10 Nonlinear characteristics of control valve

作用したときの応答を解析する，時間刻み $\tau$ は, 原点 付近のばね定数によって決まる固有周期 $(0.063 \mathrm{~s})$ の 1/20 以下である $0.001 \mathrm{~s}$ とした。このときのスプール 部変位 $x$ と加速度 $\ddot{x}$ を図 11(b), (c) に示す。これ らの図から， $\ddot{x}$ が時間 $0.3 \sim 0.7 \mathrm{~s}$ において, 時間刻み ごとに大きく振動していることがわかる.これは, 時 間 $0 \sim 0.3 \mathrm{~s}$ ではスプール部のばね定数は $k_{2}$ であるが, 時間 $0.3 \sim 0.7 \mathrm{~s}$ では $k_{1}$ となるためと考えられる.そ のため, $\dot{x}, \ddot{x}$ を用いて折れ曲がり点を予測するため には, 十分小さな時間刻みにする必要があり, 解析時 間も増加する。そこで, 時間刻みを大きくしても精度 よく折れ曲がり点を予測できる手法として, ばね定数 と時間刻みの二乗に比例した質量を付加する手法 (付 加質量法)の検討を行う.

$4 \cdot 2$ 数值積分法の性質 付加質量法による高剛 性断片線形系の数値積分における特性改善効果を評価 するために, $3 \cdot 2$ 節と同様な手法を用いて, その性質 を検討する。ここでは簡単化のため, 1 自由度のばね隇衰-質点系モデルを考える.この系の運動方程式は, 外力項を無視すると次のようになる.

$$
m \ddot{x}+c \dot{x}+k x=0 \text {. }
$$

ここで, $x=X e^{\lambda_{0} t}$ とおき整理すると, 二次系の固有值 $\lambda_{0}$ が得られる.

$$
\lambda_{0}=\alpha_{0} \pm i \beta_{0}=-\zeta_{0} \omega_{0} \pm i \omega_{0} \sqrt{1-\zeta_{0}^{2}}
$$

ここで, $\zeta_{0}=c / 2 \sqrt{m k}, \omega_{0}=\sqrt{k / m}, i=\sqrt{-1}$ である.

一方，この系に対するNewmark $-\beta$ 法 $(\beta=1 / 4)$ の特 性方程式 $z=e^{\lambda \tau}$ は, 差分方程式を $z$ 変換することに

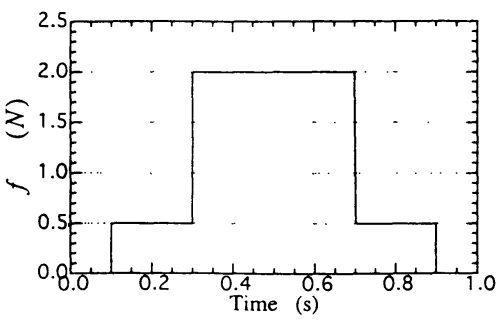

(a) Pilot force

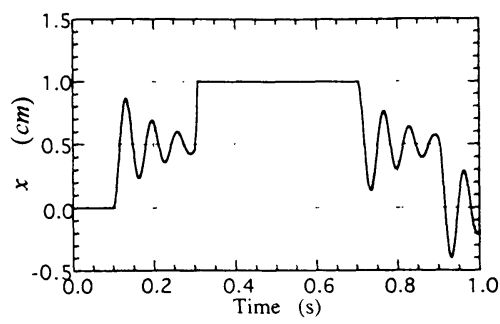

(b) Spool displacement

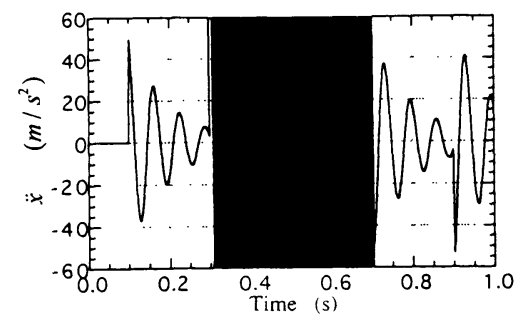

(c) Acceleration

Fig. 11 Simulation results of control valve model

よって, 次式のように与えられる(3).

$$
\begin{aligned}
(1 & \left.+\zeta_{0} \omega_{0} \tau+\frac{\omega_{0}^{2} \tau^{2}}{4}\right) z^{2}-\left(2-\frac{\omega_{0}^{2} \tau^{2}}{2}\right) z \\
& +\left(1-\zeta_{0} \omega_{0} \tau+\frac{\omega_{0}^{2} \tau^{2}}{4}\right)=0 \cdots \cdots \cdots \cdots . . .
\end{aligned}
$$

ここで， $\tau$ は時間刻みである。上式を $z$ に関して解き， さらに対数変換すると次式が得られる.

$$
\begin{aligned}
& \lambda \tau=\alpha \tau \pm i \beta \tau \\
& \alpha \tau=\ln \left|\frac{\sqrt{\left(1-\frac{\omega_{0}^{2} \tau^{2}}{4}\right)^{2}+\omega_{0}^{2} \tau^{2}\left(1-\zeta_{0}^{2}\right)}}{1+\zeta_{0} \omega_{0} \tau+\frac{\omega_{0}^{2} \tau^{2}}{4}}\right| \\
& \beta \tau=\tan ^{-1}\left(\frac{\omega_{0} \tau \sqrt{1-\zeta_{0}^{2}}}{1-\frac{\omega_{0}^{2} \tau^{2}}{4}}\right) \\
& \zeta=\frac{1}{\sqrt{1+\left(\frac{\beta}{\alpha}\right)^{2}}}
\end{aligned}
$$

上式は系の固有值と時間刻みの積 $\lambda_{0} \tau=\alpha_{0} \tau \pm i \beta_{0} \tau$ が 


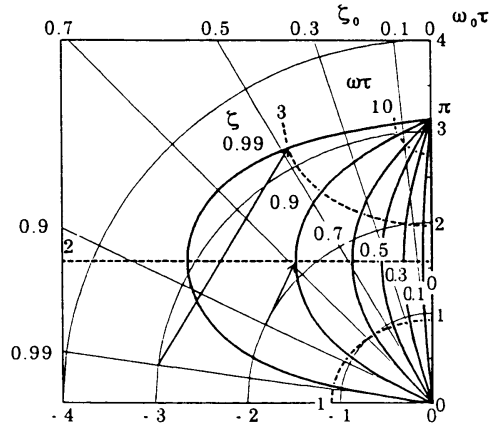

Fig. 12 Eigenvalue distortion $\lambda_{0} \tau$ vs. $\lambda \tau$

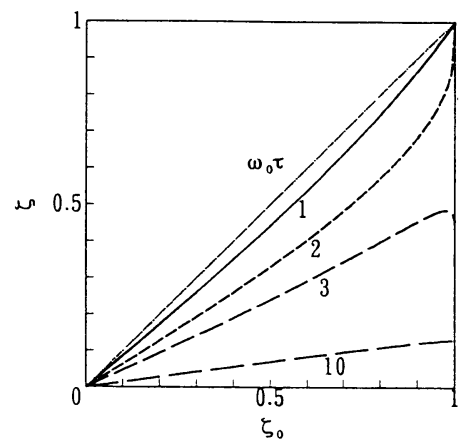

Fig. 13 Distortion of damping ratio $\zeta_{0}$ vs. $\zeta$

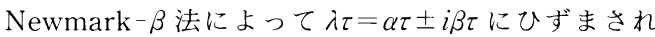
ることを示す. $\lambda_{0} \tau$ と $\lambda \tau$ の関係を図 12 に示す. 㛜密 積分計算の特性は, $\omega_{0} \tau=$ 一定の点が原点 $\mathrm{O}$ を心と した円周上に乗り， $\zeta_{0}=$ 一定の点が原点 $\mathrm{O}$ を通る直線 上に乗る．数值積分の特性根はこのような円周や直線 上に乗らない部分がひずみとして生じる.図 9 に示す 油压系では， $\omega_{0} \tau$ はコントロール弁のばね定数 $k_{2}, k_{1}$ によって $10^{-1}$ から $10^{2}$ のオーダまで変化しているこ とがわかる. $\omega_{0} \tau=10^{-1}$ では, $\alpha \tau / \alpha_{0} \tau \cong 1, \beta \tau / \beta_{0} \tau \cong 1$ と なるが, $\omega_{0} \tau=10^{2}$ では $\alpha \tau / \alpha_{0} \tau \cong 0, \beta \tau \cong \pi$ となり, 固有 值が大きくひずまされていることがわかる.

$4 \cdot 3$ 付加質量法による特性の改善 $\quad 4 \cdot 2$ 節の検 討によって高剛性断片線形要素に対しては, 時間刻み を小さくすることなく，付加質量 $\Delta m$ を与えることに よって $\omega_{0} \tau$ を小さくし，数值積分の特性を改善するこ とができそうである。しかし，あまり大きな $\Delta m$ を与 えると, 応答性が悪化し解析結果に悪影響を与える可 能性がある。そこで, 1 自由度のばね-減衰一質点系モ デルを用いて， $\omega_{0} \tau$ を変化させたときのステップ応答 特性を検討する。な扔，減衰比は $\zeta_{0}=1$ とした。

まず, $m$ を変化させることによって $\omega_{0} \tau$ を変化さ せたときの解析結果を, 図 14 に示す。この図から, $m$

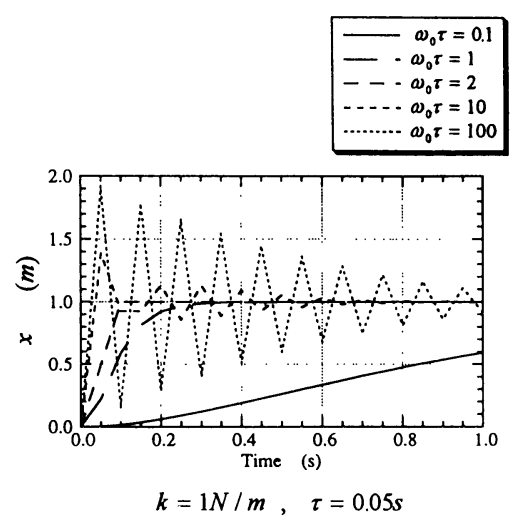

Fig. 14 Step response characteristics by adding mass

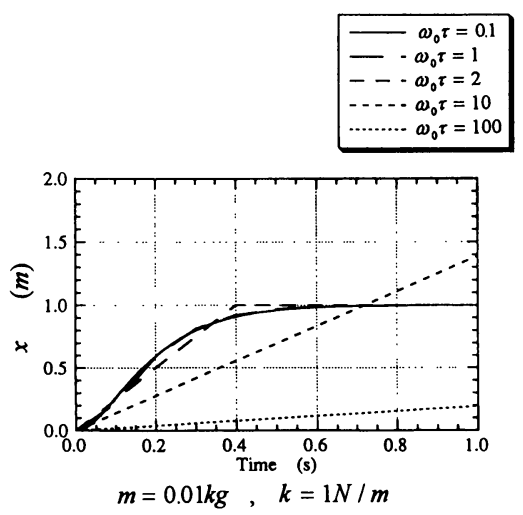

Fig. 15 Step response characteristics by changing time step

を大きくして $\omega_{0} \tau$ を小さくすると, 変位 $x$ が滑らか に変化しているが, $m$ を小さくして $\omega_{0} \tau$ を大きくす ると, $x$ の変化が激しくなり, $\omega_{0} \tau=10^{2}$ では時間刻み ごとに振動していることがわかる.

一方, $\tau$ を変化させることによって $\omega_{0} \tau$ を変化させ たときの解析結果を図 15 に示す。この図から，時間 遅れは $\omega_{0} \tau=1$ までは大きくないことがわかる。しか も, このときの固有周期は $T=2 \pi / \omega_{0}=2 \pi \tau$ となって いることがわかる，通常，時間刻み $\tau$ の選定に際して は, 解析したい挙動を十分表現できる程度に小さくし ており， $\omega_{0} \tau=1$ となるように $m$ を決めても応答性に は影響を与えないことがわかる。

さらに, $\omega_{0} \tau=1$ のときの $\zeta_{0}$ と $\zeta$ 関係は図 13 に 示すように, ほぼ直線的に変化しており, 減衰率のひ ずみはほとんど発生しないことがわかる。

以上の検討結果から, 高剛性断片線形要素に対して は, $\omega_{0} \tau=1$ すなわち $\Delta m=k \tau^{2}$ となるように付加質量 


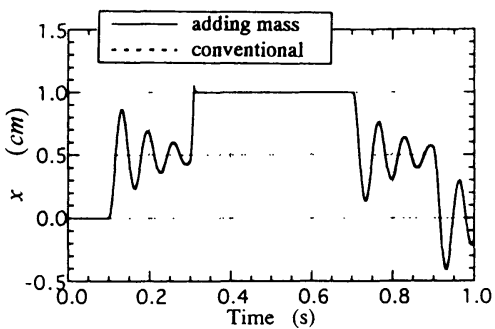

(a) Spool displacement

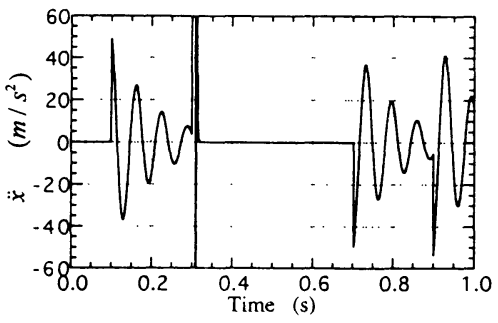

(b) Acceleration

Fig. 16 Simulation results by adding mass

を与えることによって，応答性に影響を与えず，しか も変位 $x$ および加速度 $\ddot{x}$ の精度が向上することによ って，折れ曲がり点の予測を容易にすることができ る.

$4 \cdot 4$ 解析例 ここでは, 付加質量法の妥当性を 検証するために，図 9 に示した油圧系の解析を行う。 $4 \cdot 3$ 節において示したように,スプールストッパ部の ばね定数 $k_{1}$ に比例した付加質量 $\Delta m=k_{1} \tau^{2}$ を計算し， ストッパに当たっているときのみスプール部節点に組 込み，図 11 と同様の解析を行った。その結果を図 16 に示す．この艮から，時間 $0.3 \sim 0.7 \mathrm{~s}$ においても加速 度 $\ddot{x}$ の変動は小さく抑えられており，しかも変位の 応答性に関しては，付加質量を与えていないときの結
果と同等であることがわかる。 また, 折れ曲がり点通 過に関する繰返し計算回数は, 75 回から 7 回に減少し ている.

\section{5. 結言}

スティフな断片線形要素を含む系の時刻歴応答解析 において，時間刻みに対応する付加質量を与える手法 (付加質量法)について検討した。 その結果, 以下の結 論を得た。

（1）高減衰 $c$ を有する断片線形要素に対しては, 付加質量 $\Delta m$ として,$\Delta m=c \tau$ を付加することによっ て数值積分の特性を改善することができる。しかも， 応答性に関しては, 時定数が時間刻みとなり, 実用上 問題ない.

（2）高剛性 $k$ を有する断片線形要素に対しては, 付加質量 $\Delta m$ として,$\Delta m=k \tau^{2}$ を付加することによ つて数值積分の特性を改善することができる.しか も, 応答性に関しては, 固有周期が時間刻みの $2 \pi$ 倍 となり, 実用上問題ない.

（3）本手法を用いることによって，チエック弁や コントロール弁を含む油圧パワーラインの動的シミュ レーションを効率よく，しかも夕フに解析できる.

最後に, 本研究を進める上で貴重なご助言をいただ いた芦屋大学藤川猛教授に深く感謝の意を表す。

\section{文献}

（1）藤川猛・ほか 2 名, R\&D 神戸製鋼技報, 34-3(1984), 109-110.

（2）今西悦二郎・ほか 3 名, 機論、53-492, C (1987), 1711 1719

（3）清水信行・ほか 4 名, 機論, 46-401，C (1980)，26-41

(4) 廣岡栄子・井上喜雄, D\&D 講演論文集, No. 940-26 (1994), 113-116 